\title{
ESP AFTER THIRTY YEARS: AN OVERVIEW OF THE POSITION OF ESP IN THE 1990s
}

\begin{abstract}
In the view of many ESP practitioners and thinkers, the year 1962 has increasingly been considered the year which marks the birth of ESP, the son of ELT (see, for example, Swales 1985: 1-3). The year 1992 could mark the thirtieth birthday of ESP which is a good opportunity to reconsider the sttus of ESP, which is arquably now. The article of Barber (1962) 'Some measurable characteristics of modern scientific prose? indicated clearly the birth of ESP. On the basis of these considerations, the principal aim of this paper is to take a fresh look at ESP and its status in terms of its current issues and recent drawbacks.
\end{abstract}

\section{The recent position of ESP in relation to ELT}

Although there has been a common agreement among ESP practitioners, applied linguists, etc. that ESP should not be separated from ELT (Mackay and Mountford 1978 and Widdonwson 1983: 83, for instance), the real and actual conditions of ESP demonstrate that it has started to distant itself from ELT. In fact, the recent circumstances of ESP show celarly that there have been some general trends which are ESP bound and perhaps have nothing to do with ELT.

The very specific purpose which always characterizes ESP is not a pre-requisite or a demand in ELT or General English (henceforth GE), for instance. What logically follows from this is that as ESP has usually a specific purpose, which could be EST (English for Science and technology), EOP (English for Occupational Purposes), etc., it will inevitably result in a product different from that of ELT:

Put differently, in ESP learners as well as teachers have usually a speficic purpose in mind related to their target situation, whereas GE learnes and teachers do not have this kind of specificity. The former set of learners may need this specific purpose to survive on other courses (see also Robinson 1980: 5-6). Consequently, what does not coincide with this objective could be easily rejeccted. On the contrary, the latter set of learness follow objectives which are based on general educational aims. In other words, objectives and purposes in ESP could be extracted and squeezed from other issues (e.g., needs analyses, target situations, etc.), while the objectives of GE or ELT in general are not usually based on specific objectives but rather on hypothetical and educational considerations formed by teachers or educationalists.

In addition, 'team teaching', a technique which requires the involvement of both ESP teachers and subject teachers, has always been paised as an ideal and efficient 
practice in ESP (for more detail see Robinson 1991: 88-92 and Swales 1985: 138). Nevertheless, this method of teaching may not be needed in ELT in general or in GE and, as a result, it may not be important at all in this respect.

The aforementioned issues tend to suggest that ESP has started gradually to distant itself from ELT. That is to say, ESP specific purpose, product and team teaching suggest the emerging independence of ESP, particularly in these early 1990s. Supporting our argument in Robinson (1991: 96) who implicitly admits this points by stating:

"Being and ESP teacher is not easy. One of the prime requisites would seem to be plexibility and a willingness to try new approaches and methods. Whatever the training that is given to an ESP teacher and whatever the situation, it is probably the case ... that becoming and effective teacher of ESP requires 'more' experience, 'additional' training, 'extra' effort, a'fresh' commitment, compared with being a tacher of general English".

The quotation suggest the increasing demands of ESP and the increasing differences between ESP and GE. That is to say, the independence of ESP could now be observed on the hozizon, but the complete and full independence may require some time to reach us.

\section{Inconsistency of ESP publications}

Browsing in the literature written on and for ESP, one notices the increasing abundance in publications. The bulk of these publications took place in 1980s (e.g., Adkins and McKean 1983, Hutchinson and Waters 1984, Chaplen 1981, etc.). This point is echoed by Ewer and Boys (1981: 87) who state:

"Most teachers and program organisers would agree that textbooks occupy the key position in an EST program, and in recent years there has been a notable increase in their numbers. At the same time, a great deal has been published about the design of syllabuses and the production of material for ESP ...".

Nonetheless, two negative points about these publications can be noted. First, ESP coursebooks may not always meet the expectations of the ambitious ESP teacher on the spot. Although these books usually include a very attractive cover page in terms of the title of the book, design of cover pade, content, practicality, etc., one easily notices the shortcomings and shortages of these books. Whereas one finds an ESP book which includes some practical units, he, simultaneously, could be frustrated when it comes to the other units addressed in that book which may not match the expected level the ESP teacher hopes to find (e.g., Chaplen 1981 and Bates and Dudley-Evans 1976). In other words, the range of skills and sub skills dealt with in these books is very wide and sometimes it includes a number of simple ideas designed only to beginners. At the same time, it includes difficult ideas that, for instance, match only the requirements of ESP advanced students (e.g., Adkins and McKean 1983). 
The second unfortunate point about these publications is their inconsisency of focus. For example, Widdowson's series (1979) Reading and Thinking in English focuses on the reading skill and ignores the other three macro skills (writting, listening and speaking. Bates and Dudley-Evans (1976) Nucleus: General Science emphasizes grammatical structures required in ESP situations and ignores reading, for instance. Adkins and McKean (1983) Text to Note concentrates mainly on listening and ignores speaking and many other necessary writing aspects.

Limitations os space and time prevent us from dealing with other published coursebooks. But the general tendency indicated that some ESP textbooks are at fault. Of course, we are aware that ESP situations are many and different and, therefore, it may be difficult to find a tailormade coursebook that could suit all situations. However, our point is the clear inconsistency in addressing the macro skills (major skills: reading, writting, listening and speaking) regardless of the other situations which are needsbased. Is it not true that an ESP learner could need and/or want reading to read his relevant texts, writing to write in exams and do assignments, listening to understand lectures, presentations, talks, etc. and speaking to express himself on the one hand and perhaps to operate well in his oral exams?

\section{People involved in ESP}

Originally, in the early stages of ESP (e.g., 1960s and 1970s), most ESP teachers, course designers and programme directors were ELT teachers (both from ESL and EFL) coming from the environment of GE (Hutchinson and Waters 1987: 1). Reluctantly or enthusiastically, these people found themselves new settlers in the environment of ESP. And the number of these people have been increasing year after year.

Celebrators of the thirtieth birthday or anniversary of ESP could now dare to consider themselves a real community though they are scattered over all the world. This is natural as ESP has been largely consumed outside UK and USA. The important developments in Latin America (e.g., the series of Reading and Thinking in English which was based on the University of Andes, Bogota, Colombia, see also Swales 1985: 157), the Middle East universities which even run M.As in ESP (e.g., University of Mosul, Iraq, see Robinson 1980: 77), the establishment of ESPMENA in Khartoum, Sudan and many other important developments indicate that the people involved in ESP are many and will be more that one expects because English has attained an important status in the worls and will remain the Lingua Franca of the world.

Finally, it is worth noting that in certain academic institutions (e.g., Jordanian universitis), the number of ESP teachers exceeds the number of GE teachers. In general, it may follow from this point that the number of ESP practitioners will increase and perhaps will become dominant, at least in the development countries, where English is usually spoken as foreign or second language. The United Nations reports that two thirds of the engineering world literature, for instance, has been written in English, 
while only one third of the world engineers speak English (Naerssen and Kaplan 1987: 86.90). On top of this is the fact that the dominant language in the information networks (e.g., computer networks, satellite networks,

etc.) has been always English. Eventually, English has become the language of industrial nations and badly needed by countries which look forward fo developing their industrial capability to obtain their scientific and tehnological independence. It is also highly likely that UK and USA will continue to be the leading nations in the field of industriy. All these factors coincide and put much emphasis on the need of ESP, particularly EST and, as a result, increase the number of ESP practitioners in different parts of the world.

\section{The prestigious side of ESP}

It is very difficulty to overlook an important aspect of ESP in this paper, which is EST (English for Science and Technology). It is fair to claim that EST is the most prestigious branch in ESP. For this reason a large number of ESP practioners consider EST the branch which reflects the development of ESP in general. Therefore, most of the ESP key issues and problems can be clearly seen through the development of EST. This view is evident in Swales' argument (1985) addressed in his introduction:

"With one or two exceptions... English for Science and Technology has always set and continues to set the trend in theoretical discussion, in ways of analysing language, and in the varienty of actual teaching materials".

Hutchinson and Waters echo the same point by noting that:

"It will be noticeable ... that one area of activity has been particularly important in the development of ESP. This is the area usually known as EST (English for Science and Technology)" (1987: 9).

These viewpoints seem to suggest that EST will remain the most prestigious branch in ESP. We believe that it will remain so in terms of the people involved in it, the publications made for it and the important developments which have been shown by it.

\section{Essentiality of ESP needs analysis}

although register analysis, the focusing on the type of texts to find the liguistic properties of these texts, was used widely in the early stages of ESP, the literature written on ESP shows, in general, that needs analysis in the heart of ESP. It is a central concept that has been considered inevitable before designing any purposeful and succesful ESP course. Munby (1978), Mackay and Mountford (1978), Widdowson (1983), McDonough (1984), Hutchinson and Waters (1987), White (1988), Brindley (1989), 
Mustapha et al. (1989) and Robinson (1980, 1989 and 1991) consider needs analysis a vital pre-requisite to the specification of ESP students needs.

The overall tendency suggests that the vast majority of these practitioners insist on the importance of this issue and perhaps consider it the infrastructure of any purposeful and succesful course. Limitations of space and time prevent us from delving in the components of needs analysis. It would be enough in this context to draw the attention of the reader to the importance and perspective of needs analysis in ESP.

What follows from the above discussion is that needs analysis is associated with ESP and the success or failure of ESP courses could heavily depend on it (e.g., the way it is conducted). For example, needs analysis is not a key issue in GE as the purpose in $\mathrm{GE}$ is not specific as mentioned above. Because of these considerations, needs analysis has enabled ESP course designers to come up with tailormade syllabuses geared to students' needs.

In short, register analysis is not used any more to identify ESP learner needs. And needs analysis has been widely used for this purpose. In conclusion, it is quite clear that needs analysis will continue to serve this purpose and will be considered a crucial issue in ESP.

\section{Negligence of speaking}

Reviewing the literature of ESP, one notices that from the birth of ESP (1962) to its adulthood (1992) the skill of speaking has always been a neglected area, and the literature has concentrated on other macro skills: reading, writing and listening. Yet, speaking is an important skill from the ESP students' perspectives. For examle, Tawfiq (1984: 85-98) found that EST students at Almustansiryja University, Iraq, needed the skill of speaking to survive in their subject faculties. And, therefore, he recommended emphasis on the micro skills of speaking.

In fact, the importance of speaking is logical as students need it to interact with their subject and ESP teachers. This point is expressed by Bygate (1987), in his introduction and Bygate considers speaking as an important skill in the classroom. Moreover, most of the points dealt with above are alsoechoed by Robinson (1991: 105) who notes that:

"Speaking in EAP is a relatively meglected area. In needs analyses it normally emerges as the least needed skill ... if not a need, speaking is often a want, since in many students' opinions oral proficiency is the best indicator of mastery of a language. WAP speaking involves participation in tutorials and seminars, asking questions in lectures, oral presentations, and social interaction with other students".

Nevertheless, thirty years have passed and the ESP work reported focused on other skills. It is time to draw the attention of ESP practitioners and thinkers not to overlook 
this important skill. More research and studies are needed on the speaking skill, if we are to serve ESP and its increasing students and staff.

\section{Conclusion}

There are two key points to remember on the thirtieth birthday of ESP. The first is that ESP has imposed itself on many academic institutions (e.g., universities as in the case of EAP) and on many companies (as in the case of EOP). ESP has survived and will continue to exist. It also has become a well-established approach as it continues to distant itself from ELT. Therefore, it could be predicted that the day will come to see ESP an independent discipline, not, for instance, a parasite which exists on other disciplines.

The second point is that many important changes have taken place in ESP. Starting from the change of emphasis from register analysis to the increasing number of its practitioners and thinkers. However, ESP still in need of much research and work to cover its neglected areas, to make its published textbooks of more value and practicality and to make it completely effective. ESP concerned people should strike a balance in the coursebooks they write and, as a result, they need to cover ESP skills and sub-skills comprehensively.

\section{Bibliography}

Adkins, A. and McKean, I. (1983) Text to Note: Study Skills for Advances Learners, London: Edward Arnold.

Allen, J.P. (1984) 'General-purpose language teaching: a variable focus approach'. ELT Documents 118.General English Syllabus Design. Oxford: Pergamon Press in association with the British Council. pp. 61-74.

Allen, J.P. and Widdowson, H.G. (1985) 'Teaching the communicative use of English' in Swales J. (ed.) Episodes in ESP.Oxford: Pergamon. pp. 69-79. in association with the British Council. pp. 109-116.

Barber, C.L. (1985) 'Some measurable characteristics of modern scientific prose' in Swales, J. (ed.) Episodes in ESP. Oxford. Pergamon. pp. 1-17.

Bates, M. and Dudley-Evans, T. (1976) Nucleus: General Science. London: Longman.

Brindley, G. (1989) 'The role of needs analysis in adults ESL programme design' in Johnson, K. (ed.) Second Language Curriculum. Cambridge: CUP.

Bygate, M. (1987) Speaking. Oxford: OUP.

Chaplen, F. (1981) A Course in Intermediate Scientific English. London: Evans Brothers.

Ewer, J.R. and Boys, O. (1981) 'The EST textbooks situation: An enquiry', The ESP Journal, vol. 1, no. 2. pp. 87-105. 
Hutchinson, T. and Waters, A. (1984) Interface: English for Technical Communication. Harlow: Longman.

Hutchinson, T. and Waters, A. (1985) 'ESP at the crossroads' in Swales, J. (ed.) Episodes in ESP. Oxford: Pergamon. pp. 174-187.

Hutchinson, T. and Waters, A. (1987) English for Specific Purposes. Cambridge: CUP. Mackay, P. (1981) Languages for Specific Purposes: Program Design and Evaluation. Rowley, MA: Newbury House.

Mackay, R. and Mountford, A. (ed.) (1978) English for Specific Purposes. London: Longman.

Mackay, R. and Mountford, A. (1979) 'Reading for information', in Mackay, R. et al. (ed.) Reading in a Second Language. Rowley, MA: Newbury House. pp. 106-41.

McDonough, J. (1984) ESP in Perspective: A Practical Guide. London: Collinn.

Munby, J. (1978) Communicative Syllabus Design, Cambridge: CUP.

Mustapha, H. et al. (1989) 'A course for first year students of the college of earth science'. ELT Documents 103: ESP for the University. Oxford: Pergamon Press in association with the British Council. pp. 95-104.

Naerssen, M.V. and Kaplan, R.B. (1987) 'Language and science', annual Review of Applied Linguistics. vol. 7. pp. 86-105.

Nunan, D. (1988) Syllabus Design. Oxford: OUP.

Robinson, P.C. (1980) ESP (English for Specific Purposes): The Present Position. Oxford: Pergamon.

Robinson, P.C. (ed.) (1988) Academic Writing: Process and Product. ELT Documents 129. Modern English Publication in association with the British Council.

Robinson, P.C. (1989) 'An overview of English for Specific Purposes', in Coleman H. (ed.) Working with Language: A Multidisciplinary Consideration of Language Use in Work Contexts. Contributions to the Sociology of Language 52, Berlin: Mouton de Gruyter. pp. 395-427.

Robinson, P.C. (1991) ESP Today: A Practitioner's Guide. Hemel Mehpstead: Prentice Hall.

Swales, J. (ed.) (1984) ESP in the Arab World. Birminghan: Aston University.

Swales, J. (ed.) (1985) Episodes in ESP. Oxford: Pergamon.

Tawfiq, A. (1984) 'A communicative EST reading skills course for students at the Faculty of Medicine in Iraq: a case study', in Swales, J. (ed.) English for Specific Purposes in the Arab World. Birmingham: Aston University. pp.85-98.

White, R. (1988) The ELT Curriculum: Design, Innovation and Management. Oxford: Blackwell.

Widdowson, H.G. (ed.) (1979) Reading and Thinking in English: Discovering Discourse, Oxford: OUP.

Widdowson, H.G. (ed.) (1979) Reading and Thinking in English: Exploring Function. Oxford: OUP.

Widdowson, H.G. (1983) Learning Purpose and Language Use. Oxford: OUP

Widdowson, H.G. (1984) ' Education and pedagogic factors in syllabus design'. ELT Documents 118. General English Syllabus Design. Oxford: Pergamon Press in association with the British Council. pp. 23-28. 
Widdowson, H.G. (1987) 'Aspects of syllabus design' in Tickoo, M. (ed.), Syllabus Design: the State of the Art. Singapore: Regional English Language Centre. Nottingham.

Yalden, J. (1983) The Communicative Syllabus: Evaluation, Design and Implementation. Oxford: Pergamon.

Yalden, J. (1984) 'Syllabus design in general education: options for ELT'. ELT

Documents 118. General English Syllabus Design. Oxford: Pergamon Press in association with the British Council. pp. 13-22.

Yalden, J. (1987) Principles of Course Design for Language Teaching. Cambridge: CUP.

Yates, C. (1989) Agriculture. London: Cassell.

Povzetek

ESP PO TRIDESETIH LETIH: NJEGOV POLOŽAJ V DEVETDESETIH LETIH

Vedno več teoretikov in praktikov ESP /English for Specific Purpose/ ima leto 1962 za začetek poučevanja ESP. Leto 1992 je torej zaznamovalo trideseto obletnico ESP, kar je bila priložnost za ponovno vrednotenje njegovega statusa, ki je še zmeraj sporen. Rojstvo ESP je pomenil Barberjev članek (1962) 'Nekatere izmerljive značilnosti moderne znanstvene proze'. Glavni namen tega prispevka je na novo pretehtati ESP in njegov status danes. 